\title{
PRICE CHANGES OF BASIC NEEDS ON THE POVERTY LEVEL
}

\author{
Indra Maipita ${ }^{1}$ \\ imaipita@gmail.com \\ Fahrurrozy ${ }^{2}$ \\ Setyo Tri Wahyudi ${ }^{3}$ \\ Fitrawaty $^{4}$ \\ Universitas Negeri Medan ${ }^{1,4}$ \\ Jl. Rumah Sakit H., Kenangan Baru, Deli Serdang, Sumatera Utara 20371 \\ Universitas Graha Nusantara ${ }^{2}$ \\ J1. Sutan Soripada Mulia No.17, Wek II, Padang Sidempuan, Sumatera Utara 22711 \\ Universitas Brawijaya ${ }^{3}$ \\ Jl. Veteran, Ketawanggede, Kec. Lowokwaru, Kota Malang, Jawa Timur 65145
}

received: 8/10/20; revised: 29/10/20; approved: 14/12/20

\begin{abstract}
Poverty is often identified in developing countries. One measure of poverty is the ability to fulfill basic needs, particularly food needs. On the other hand, food needs are very sensitive to changes in inflation. The morefluctuating inflation will change the prices of necessities, which then exacerbate poverty conditions. Using time-series data for the period 2005-2016 and using the Ordinary Least Square method, this study examines the impact of changes in the prices of necessities on poverty levels in North Sumatra. The results showed that the increase in rice prices, sugar, cooking oil, beef, and salt had an impact on the poverty level in North Sumatra, while the increase in the price of eggs and kerosene was the opposite. The increase in rice prices significantly impacted all of the commodities studied than for other commodities, followed by salt, sugar, beef, and cooking oil. Changes in the ability to consume basic needs indicate a decrease in people's purchasing power. Further, this indicates that the change in consumption of these various commodities also means that the poverty rate tends to increase.
\end{abstract}

Keywords: poverty; price changes of basic needs; welfare; ordinary least square; North Sumatra

\section{INTRODUCTION}

Poverty is not a new phenomenon in every country. It is a social phenomenon that has been an attribute of developing countries. This phenomenon is also the opposite of the conditions experienced by developing countries that have attributes as a modern country. It seems that poverty is identical and has been embedded in developing countries' structure and has become a serious enough problem to get treatment from state administrators.

Poverty is a crucial issue and one of the most complex problems for many countries (Hung \& Makdissi, 2004; Marianti \& Munawar, 2006; Maipita et al., 2010; Maipita et al., 2012; Maipita et al., 2016). Even though there have been many efforts made by state administrators, the problem of poverty is like untangle the threads that are difficult to find a solution for. It is estimated that there is something wrong with the formulation and implementation of policies to eradicate poverty and empowering the poor (Suryawati, 2005).

Most of the Indonesian people's per capita expenditure is still used to buy food, which is an immediate need that must be fulfilled to make people survive (Widayaningsih \& Barokatuminalloh, 2016). Although basic needs experience a downward trend, consumer expenditure on food is still around 50 percent of the total expenditure (Hermawan et al., 2017). Therefore, Statistics Indonesia determines the poverty threshold based on the price of basic needs. In other words, food price fluctuations will directly affect the poverty threshold and the poverty rate.

The various research results show that food price increases will have an impact on purchasing power and poverty levels (Headey, 2014; Ivanic \& Martin, 2008; Huang \& Huang, 2012; Shrestha \& Chaudhary, 2012; Hoyos \& Medvedev, 2016; Minot \& Goletti, 2000; Maipita et al., 2012; Maipita et al., 2016). If 
we look at the Statistics Indonesia report, the poverty rate decline was caused by some factors, namely the decline in inflation and stable rice prices (Rofiq, 2013).

The inflation factor and rice prices are deeply felt by the poor in rural areas. Improving inflation and stable rice prices have greatly helped reduce the number of poor people in rural areas because all this time the villagers have been very dependent on the rice. Inflationary pressures can also cause pressure on people's purchasing power, especially for groups of people who are categorized as poor and near-poor.

Nugroho \& Dahuri (2012) said that poverty is an absolute or relative condition, namely the condition of a person or group of people in an area due to natural, cultural, or structural reasons that cause a person or group not to have the ability to meet their basic needs following specific values or norms prevailing in the society. This condition shows that our poverty is enormously rising for goods (inflation) and rising prices for basic needs (Rofiq, 2013). If inflation rises, the number of poor people also increases. If the price of rice rises, many rural people will fall into the low category. That is why, in Indonesia, stable rice prices have been the mainstay of policymaking for more than four decades (Kajisa \& Akiyama, 2005).

Sugar, as one of the basic needs, also has its problems. As an agricultural country and known as an exporting country, Indonesia, unfortunately, does not focus on basic needs. Indonesia tends to produce non-basic needs such as rubber, copra, and coffee. Sugar is one of the most common food staples. It obtained by importing, causing the price of this food staple to fluctuate frequently (Warr \& Yusuf, 2013).

Based on the disclosed data, it can be seen that the highest inflation rate of basic needs is kerosene, followed by rice, and the lowest inflation rate of basic needs is the egg. Even though the rice inflation rate is at the secondhighest level, and considering rice is the most basic need of the Indonesian people, rice prices will directly and significantly affect the number of poor people. This is because the citizens of North Sumatera are still very dependent on rice, so that an increase in rice prices will directly affect the level of poverty. This is very interesting to study, so the researchers formulated research objectives to analyze the impact of price changes on the poverty level in North Sumatera Province.

\section{METHOD}

This study used secondary data in which the information is obtained indirectly. Secondary data used in this study is time-series data from one observation period from 2005 to 2016 . The data source was obtained from Statistics Indonesia. This study used descriptive analysis and Ordinary Least Square (OLS) analysis to measure price changes of basic needs that affect North Sumatra's poverty.
This study explained the effect of price changes on basic needs, namely rice, sugar, cooking oil, beef, chicken egg, kerosene, salt, and poverty in North Sumatera, which were formulated in functions:

$$
\begin{aligned}
\mathrm{POV}= & \alpha_{0}+\alpha_{1} \mathrm{dRICE}+\alpha_{2} \mathrm{dSUGAR}+\alpha_{3} \mathrm{dOIL}+\alpha_{4} \mathrm{dBEEF}+ \\
& \alpha_{5} \mathrm{dEGG}+\alpha_{6} \mathrm{dKEROS}+\alpha_{7} \mathrm{dSALT}+\mu \ldots \ldots . .(1)
\end{aligned}
$$

Information:

$$
\begin{array}{ll}
\text { POV } & =\text { Poverty Rate (percent) } \\
\text { dRICE } & =\text { Rice Price Change (percent) } \\
\text { dSUGAR } & =\text { Sugar Price Change (percent) } \\
\text { dOIL } & =\text { Oil Price Change Goreng (percent) } \\
\text { dBEEF } & =\text { Beef Price Change (percent) } \\
\text { dEGG } & =\text { Egg Price Change (percent) } \\
\text { dKEROS } & =\text { Kerosene Price Change (percent) } \\
\text { dSALT } & =\text { Salt Price Change (percent) } \\
\alpha_{1}, \alpha_{2}, \alpha_{3}, \alpha_{4}, \alpha_{5} & \\
\alpha_{6}, \alpha_{7}, \alpha_{8}, \alpha_{9} & =\text { Regression coefficients } \\
\mu & =\text { errorterm (nuisance error) }
\end{array}
$$

\section{RESULTS}

The impact of price changes of basic needs on the poverty level will estimate using equation (1). The results were shown in Table 1. Based on the estimation results, it is known that all independent variables show a significant effect on the poverty level using a 10 percent confidence level. Further, based on Table 2, we can see that the correlation between the independent variables did not exceed 0.8 ; it means that the model's estimation results were free from multicollinearity symptoms.

\section{DISCUSSIONS}

Based on the results, rice price change was proven to impact increasing the number of poor people. The rice price was increased by $1 \%$ and could increase the number of poor people by 0.261 percent. This indicates that, based on Statistics Indonesia data for the period 2005-2016, it turned out that the rice price had a significant impact on the number of poor people in North Sumatera. This was because civil society in North Sumatera still relies on rice as the staple food. This condition made rice price a benchmark for economic indicators. So, if the prices of rice increased, it would directly affect the number of poor people. People who are slightly above the poverty line will fall below the poverty line, thus increasing the number of poor people. The result in line with Rofiq (2013) which stated that poverty is enormously rising for goods (inflation) and rising prices for basic needs.

This study's results were not different from the results of research by Ravallion \& Walle (1991), who found that an increase in rice prices will impact poverty levels and people's purchasing power. This is not different from what Shrestha \& Chaudhary (2012) 
found that an increase in rice prices will impact people's purchasing power and ultimately impact the level of poverty. Likewise with a study conducted by Hoyos \& Medvedev (2016) which states that when rice price rises, the share of income spent on food (rice) also increases, dragging people who are at the poverty line, making them into the low category. Prices of other goods and services, including rice, ultimately affect production power, employment, purchasing power, and poverty and inequality levels (Reyes et al., 2010). Fluctuations in rice prices will impact people's purchasing power (Shrestha \& Chaudhary, 2012) and ultimately have an impact on poverty levels. Increasing the rice price will increase the number of poor people (Rofiq, 2013).

Researchers suggest that there are variations in staple food other than rice consumed by the people of North Sumatra because the poor tend to allocate their income as a staple food. This statement is supported by Cranfield et al. (2006) that the poorest people spend about three-quarters of their income on staple foods. Besides, regulators can strive for programs to plant various staple foods other than rice that do not require sizeable agricultural land such as corn using the hydroponic method. Furthermore, people who need rice assistance and entrepreneurship programs are needed by selling crops from hydroponic plants that do not require large land areas and are relatively consumed daily, such as chilies.

The rising rice prices should reduce the number of poor people because the poor are concentrated in rural areas, and generally, their livelihood is by farming rice. The average area of agricultural land owned by the poor is 0.3 hectares, making it difficult for them to increase income. Ideally, farmers should own agricultural land with an area of 2 hectares perennial so that their results will be sufficient to meet household needs (Rofiq, 2013). On the other hand, the real farmer exchange rate tends to be below 100. It means that the value of farmer exchange rate after being eroded by inflation will result in farmers' low income and purchasing power. Besides that, the selling price of unhauled rice is far below the price of rice.

The estimation results show that sugar price change positively correlates to the poverty level in North Sumatera. This meant that the higher the price of sugar in North Sumatra, the more poverty in North Sumatra increased. The coefficient of sugar price change was 0.106 , which meant that the sugar price was increased $1 \%$, and it could increase the number of poor people by 0.106 percent

Based on the research results, it was known that the sugar price had a positive and significant correlation to poverty in North Sumatera. The need for granulated sugar must indeed be fulfilled, considering that granulated sugar is indeed a food material used by the community in meeting the need for calories. Granulated sugar is usually consumed by the community to make drinks in the morning and evening. It is also used as a kitchen spice.

The need for sugar will increase during Ramadan. People who are at the poverty line or poor people will meet their sugar needs. So that those who are at the poverty line fall into the category of poor people. From the BPS report, sugar consumers from year to year continue to experience an increase in line with population growth. Sugar consumers increase from year to year, while sugar price also increases (Rofiq, 2013). Therefore, the increase in sugar prices increases poverty. It is hoped that the regulator can support community empowerment by increasing sugar commodities' productivity by establishing a sugar factory. The existence of a sugar factory will increase people's economy and reduce poverty. This statement is in line with Krivonos \& Olarreaga (2006) that workers in the sugar sector and sugar-producing areas have better job opportunities and experience more significant wage increases. Furthermore, households can increase their income because they can get out of unemployment.

Furthermore, support is needed from the monitoring and control teams of regional inflation in each region to monitor the increase in commodity prices, which are generally consumed daily, such as the need for sugar. Also, to reduce the sugar price, community activeness is needed apart from monitoring and control team of regional inflation, where if the selling price set by distributors, sub-distributors, or other sugar traders is above maximum retail price (MRP), it can be conveyed to regulators such as Ministry of Trade. It is hoped that people with low income will not be affected by this commodity's purchasing power.

The estimation results showed that cooking oil prices' changes had a positive correlation with poverty in North Sumatera. This meant that the higher the price of cooking oil, it would increase the number of poor people in the province. The regression coefficient for the change in cooking oil price is 0.048 . This meant that if the cooking oil price was increased by $1 \%$, it could increase the number of poor people by 0.048 percent.

The results showed that changes in cooking oil prices had a positive correlation with poverty in North Sumatera. This meant that the higher the price of cooking oil, it would increase the number of poor people in the province. The regression coefficient for the change in cooking oil price is 0.048 . This meant that if there were an increase in cooking oil price by 1 percent, it would increase poverty by 0.048 percent. The increasing price of cooking oil causes the number of poor people also to increase. The poorest households were most affected by the increase in oil prices.

Cooking oil as a non-essential food commodity also had an essential role in the life of the people of North Sumatera. In the context of food availability, its role is a complementary material and a strategic commodity for the Economy of Indonesia, so that its 
price and distribution need to be controlled by related institutions. Moreover, Statistics Indonesia also noted another factor that caused the poverty rate to increase was the increase in retail prices for basic needs. From September 2019 to March 2020, nationally, the retail price of basic needs such as rice, broiler chicken, cooking oil, egg, and sugar had increased. Statistics Indonesia reported that a sharp increase occurred in urban areas. The urban poor reached 7.38 percent; an increase compared to September 2019 of 6.56 percent. Meanwhile, the percentage of poor people in rural areas in September 2019 was 12.60 percent, increasing to 12.82 percent in March 2020.

The strategic role of cooking oil in food commodities is as a food menu. The people of North Sumatera prepare their food menu use cooking oil as an ingredient for food processing. So, the community must strive for their need for cooking oil so that there is a significant increase in the consumption of cooking oil in the people of North Sumatera from year to year. This shows how vital the need for cooking oil is to the people of North Sumatera. In this case, the regulator can monitor retail prices, especially for cooking oil commodities, so that the retail price does not violate the stipulated provisions. It is hoped that the stable retail price of this commodity will increase people's purchasing power. On the other hand, it will also increase public demand.

The estimation results showed that changes in beef prices had a positive relationship to poverty in North Sumatera. This meant that the higher the beef price, it would increase the number of poor North Sumatera people. The variable regression coefficient for changes in beef prices is 0.097 . This meant that if there is an increase in beef price by 1 percent, it will increase poverty by 0.097 percent.

Based on the research results, changes in beef prices were proven to impact the increasing number of poor people in North Sumatera. The beef price was increased by $1 \%$, increasing the number of poor people by 0.097 percent. Consumption of beef is not the primary consumption for North Sumatera people at the poverty line, especially for the poor. Beef is a food source of animal protein classified as a luxury food and relatively cannot be consumed every day, especially for very poor, near poor and vulnerable households, which constitutes $40 \%$ of Indonesia's population. To increase beef consumption, domestic beef production needs to be increased so that the beef prices are affordable for non-poor households and impoverished, low, near-poor, and vulnerable households in Indonesia. Therefore, it is crucial to monitor the prices of these commodities through market operations. As is known, if a particular day is like Eid, then the price of the beef commodity will increase. Specifically, to overcome the high demand and lack of supply of this commodity, regulators can carry out a local cattle breeding program through artificial insemination, and unique imports can also be carried out for specific days (Eid), which results in reduced beef supply and high demand.

The community usually carries out beef consumption during religious holidays and national holidays, including the near-poor and the poor. This has become a tradition for Indonesians, including North Sumatera. So that the fulfillment of the beef will have endeavored. The effect is that the consumption of beef will increase on religious holidays. There has been an increase in beef consumption in North Sumatera from year to year, both in villages and in urban areas.

The estimation results showed that changes in egg prices had a negative relationship to poverty in North Sumatera. This means that the higher the egg price, it will reduce the number of poor North Sumatera people. This meant that if there is an increase in the egg price by 1 percent, it will reduce poverty by 0.107 percent.

Based on the theory, the egg price has a positive correlation with the level of poverty, but based on the research results, changes in egg prices negatively correlate with the level of poverty. If there is an increase in the egg price by 1 percent, it will reduce poverty by 0.107 percent. This is because some of the poor people in North Sumatera have livelihoods as breeders of layer chickens, even though they are not so much. If the egg price increases, their income will increase to fulfill basic needs, so that their position will move above the poverty line. Therefore, an increase in egg price will reduce the level of poverty in North Sumatera.

Furthermore, staple foods' price plays a significant role in determining the poverty rate in urban and rural areas, which are only at 20.59 percent and 25.97 percent, respectively. According to Statistics Indonesia, the rice price is the most significant factor, followed by the cigarette price and the egg price. The negative relationship between egg prices and poverty can be caused by good coordination between cities/regions regarding the distribution process to stabilize egg prices. As an illustration, a city/region as an egg producer, whose production is large, can cooperate/supply egg with other cities/regions. When prices drop due to the high availability of eggs, they can be distributed to other areas that are the largest producers of another commodity. It is hoped that through this cooperation, the egg price can be better maintained. Besides, the increase in egg prices can be responded to by reducing poverty to be effective. It is necessary to minimize the long chain of food needs, efforts to ensure supply certainty, and secure prices through price checks so that the less fortunate can consume this commodity. Finally, protection is needed for chicken egg breeders. As an illustration, when the egg price is above Rp. 20.000 , market operations are often held by regulators to stabilize egg prices. However, when the price is below Rp. 18.000, a minimum selling price can be set for egg breeders so that they do not suffer losses. 
The estimation results showed that changes in kerosene prices had a negative relationship to poverty in North Sumatera. This means that the higher the kerosene price, it will reduce the number of poor North Sumatera people. This meant that if there is an increase in the egg price by 1 percent, it will reduce poverty by 0.035 percent.

Kerosene is a fuel commodity used by the people of North Sumatra to cook their food. Seeing this condition, many people are near-poor or poor people take advantage of this opportunity as their livelihood. They sell kerosene to meet their basic needs. Therefore, an increase in kerosene prices will reduce the level of poverty in North Sumatera.

Also, kerosene price rise can encourage people to increase kerosene sales due to the increased selling price. It can be said that the increase in the domestic price of this commodity increases business profitability and increases wages. As a result, domestic income increases, and poverty tends to decrease. It would be better if the availability of this commodity can be increased and exported to other countries to reduce poverty in a country. On the other hand, an increase in this commodity's domestic price can contribute to an increase in the purchasing power of producers of this commodity and tends to reduce poverty.

The estimation results showed that changes in salt prices had a positive relationship to poverty in North Sumatera. This meant that the beef price rise would increase the number of poor people in North Sumatera. The variable regression coefficient for changes in salt prices is 0.097 . This meant that if there is an increase in beef price by 1 percent, it will increase poverty by 0.135 percent.

Based on the research results, changes in the salt price were proven to have an impact on increasing the number of poor people. If there is an increase in beef price by 1 percent, it will increase poverty by 0.135 percent. Salt is the main spice used by people in cooking. Maybe for other spices, people may not use them in cooking, but salt has become a spice that must be used for food processing. Therefore, near poor and poor people will inevitably continue to strive to fulfill the need for salt so that the increase in the price of salt will increase the amount of rupiah that will be used and will ultimately increase the number of poor people in North Sumatera. Therefore, regulators can build industries that produce salt so that productivity increases.

On the other hand, it is crucial to develop technology that increases salt productivity in collaboration with academics. As is well known, the salt price harvested by farmers is determined by market mechanisms (supply and demand). Furthermore, if the salt harvesting was in 2019, mediators buy it for IDR 250 per kilogram and usually sell it back to the market for IDR 550 per kilogram. However, in 2020, although crop yields are decline, mediators will increase the purchase price of salt by IDR 350 per kilogram. The price determined by middlemen is, of course, detrimental to farmers. Thus, it is vital to determine the cost of salt and the bottomline market operation, from farmers to mediators to the community.

\section{CONCLUSIONS}

The focus of the study is to analysis the impact of price changes on the poverty level in North Sumatera Province. Based on the research findings and analyzing, we concluded that: 1) there is any relationship between rice prices and poverty levels in North Sumatera. The study found that if there is any increasing of rice price, the poverty level will increase; 2) the relationship between the price of sugar and the poverty rate in North Sumatera, shows that the sugar price rise will increase the poverty level; 3 ) the cooking oil price rise will increase the poverty level; 4) the beef price rise will increase the poverty level; 5) the egg price rise will decrease the poverty level; 6) changes in the kerosene price (rise) will decrease the poverty level; 7) salt price rise will increase the poverty level.

\section{REFERENCES}

Cranfield, J., Preckel, P., \& Hertel, T. 2006. Poverty Analysis Using an International CrossCountry Demand System (GTAP Working Paper No. 34). https://www.researchgate.net/ publication/23550284_Poverty_Analysis_Using an_International_Cross-Country_Demand_System

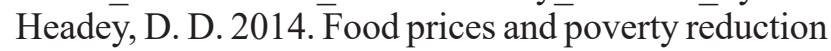
in the long run. https://www.ifpri.org/publication/ food-prices-and-poverty-reduction-long-run

Hermawan, W., Fitrawaty, \& Maipita, I. 2017. Factors Affecting the Domestic Price of Rice in Indonesia. JEJAK: Journal of Economics and Policy, 10(1), 155-171. https://journal.unnes.ac.id/nju/index.php/ jejak/article/view/9133

Hoyos, R. E. De, \& Medvedev, D. 2016. Poverty Effects of Higher Food Prices: A Global Perspective. World Bank Policy Research Working Paper No. 4887. https://papers.ssrn.com/sol3/papers.cfm?abstract_ id $=1372964$

Huang, K. S., \& Huang, S. W. 2012. Consumer welfare effects of increased food and energy prices. Applied Economics, 44(19), 2527-2536. https://doi.org/10 $.1080 / 00036846.2011 .566182$

Hung, N. M., \& Makdissi, P. 2004. Escaping the poverty trap in a developing rural economy. The Canadian Journal of Economics/Revue Canadienned'Economique, 37(1), 123-139. https:// onlinelibrary.wiley.com/doi/abs/10.1111/j.00084085.2004.006 1.x

Ivanic, M., \& Martin, W. 2008. Implications of Higher 
Global Food Prices for Poverty in Low-Income Countries (Policy Research Working Paper 4594). https://openknowledge.worldbank.org/ handle/10986/6723

Kajisa, K., \& Akiyama, T. 2005. The Evolution of Rice Price Policies over Four Decades: Thailand, Indonesia, and the Philippines. Oxford Development Studies, 33(2), 305-329. https://doi.org/https://doi. org/10.1080/13600810500138085

Krivonos, E., \& Olarreaga, M. 2006. Sugar Prices, Labour Income, and Poverty in Brazil (World Bank Policy Research Working Paper No. 3874). https://papers.ssrn.com/sol3/papers.cfm?abstract id $=935968$

Maipita, I., Hermawan, W., \& Fitrawaty. 2012. Reducing Poverty Through Subsidies: Simulation of Fuel Subsidy Diversion to Non-Food Crops. Buletin Ekonomi Moneter Dan Perbankan, 14(4), 349366. https://doi.org/https://doi.org/10.21098/bemp. v14i4.412

Maipita, I., Hermawan, W., Fitrawaty, \& Soetjipto, B. E. 2016. The Impact of Middle-Class Spending on Economic Growth and Industry In Indonesia. International Journal of Economic Research, 13(3), 813-828. http://digilib.unimed.ac.id/19582/

Maipita, I., Jantan, M. D., \& Razak, N. A. A. 2010. The Impact of Fiscal Policy Toward Economic Performance and Poverty Rate in Indonesia. Buletin Ekonomi Moneter Dan Perbankan, 12(4), 391-424. https://doi.org/https://doi.org/10.21098/ bemp.v12i4.378

Marianti, R., \& Munawar, W. 2006. Moving Out of Poverty: The Case of Desa Branta Pesisir, Kabupaten Pamekasan. http://www.smeru.or.id/ en/content/moving-out-poverty-case-desa-brantapesisir-kabupaten-pamekasan

Minot, N., \& Goletti, F. 2000. Rice market liberalization and poverty in Viet Nam (No. 114). https://www. ifpri.org/publication/rice-market-liberalizationand-poverty-viet-nam

Nugroho, I., \& Dahuri, R. 2012. Pembangunan wilayah:
Perspektif ekonomi, sosial, dan lingkungan. LP3ES.

Prianto, S. I. 2010. Kajian terhadap Pelaksanaan Kebijakan Subsidi Minyak Goreng untuk Rumah Tangga Miskin di Kota Depok. BISNIS \& BIROKRASI: Jurnal Ilmu Administrasi Dan Organisasi, 17(2), 148-159. http://journal.ui.ac. id/index.php/jbb/article/viewArticle/635

Ravallion, M., \& Walle, D. van de. 1991. The impact on poverty of food pricing reforms: A welfare analysis for Indonesia. Journal of Policy Modeling, 13(2), 281-299. https://doi.org/https:// doi.org/10.1016/0161-8938(91)90015-Q

Reyes, C. M., Sobrevinas, A., Bancolita, J., \& Jesus, J. De. 2010. Analysis of the Impact of Changes in the Prices of Rice and Fuel on Poverty in the Philippines. DLSU Business \& Economics Review, 20(1), 65-98. https://www.researchgate.net/ publication/237819272_Analysis_of_the_Impact of_Changes_in_the_Prices_of_Rice_and_Fuel_on Poverty in the Philippines

Rofiq, A. 2013. Kemajuan Ekonomi Indonesia. IPB Press.

Shrestha, M., \& Chaudhary, S. K. 2012. The Impact of Food Inflation on Poverty in Nepal. NRB Economic Review, 24(2), 1-14. https:// econpapers.repec.org/article/nrbjournl/ v_3a24_3ay_3a2012_3ai_3a2_3ap_3a1-14.htm

Suryawati, C. 2005. Memahami Kemiskinan Secara Multidimensional. Jurnal Manajemen Pelayanan Kesehatan, 8(3), 121-129. https://jurnal.ugm.ac.id/ jmpk/article/view/2927

Warr, P., \& Yusuf, A. A. 2013. World food prices and poverty in Indonesia. The Australian Journal of Agricultural and Resource Economics, 58(1), 1-21. https://doi.org/https://doi.org/10.1111/14678489.12015

Widayaningsih, N., \& Barokatuminalloh. 2016. Strategy of Increasing Food Security based on Macro and Micro Aspects. JEJAK: Jurnal Ekonomi Dan Kebijakan, 9(1), 111-128. https://doi.org/https:// doi.org/10.15294/jejak.v9i1.7190 
Table 1. The Coefficient Value of Estimation Results for Poverty Function Model

\begin{tabular}{lcccc}
\hline & Coefficient & Std. Error & t-Statistic & Prob. \\
\hline C & 7.1267 & 0.3308 & 21.5440 & 0.0000 \\
PBERS & 0.2608 & 0.0232 & 11.2152 & 0.0004 \\
PGUPAS & 0.1064 & 0.0142 & 7.4816 & 0.0017 \\
PMIGOR & 0.0484 & 0.0127 & 3.7858 & 0.0193 \\
PDASA & 0.0970 & 0.0183 & 5.2976 & 0.0061 \\
PTELA & -0.1070 & 0.0178 & -5.9894 & 0.0039 \\
PMITA & -0.0347 & 0.0128 & -2.6940 & 0.0544 \\
PGARM & 0.1348 & 0.0274 & 4.9122 & 0.0080 \\
\hline & Weighted Statistics & \\
\hline R-squared & 0.9955 & Mean dependent var & 13.1263 \\
Adjusted R-squared & 0.9877 & S.D. dependent var & 21.0822 \\
S.E. of regression & 0.2491 & Akaike info criterion & 0.2935 \\
Sum squared resid & 0.2483 & Schwarz criterion & 0.6168 \\
Log-likelihood & 6.2388 & Hannan-Quinn criteria & 0.1738 \\
F-statistic & 127.48 & Durbin-Watson stat & 1.6033 \\
Prob(F-statistic) & 0.0001 & & \\
\hline
\end{tabular}

Source: Data Proceed, 2020

Table 2. The Collinearity Among Variables

\begin{tabular}{lrrrrrrr}
\hline & \multicolumn{1}{l}{ RICE } & BEEF & SALT & SUGAR & OIL & KERAS & EGG \\
\hline RICE & 1 & 0.2778 & 0.3080 & -0.1105 & 0.5489 & 0.1953 & 0.4006 \\
BEEF & 0.2778 & 1 & 0.0526 & -0.3807 & -0.0539 & 0.3310 & 0.0469 \\
SALT & 0.3080 & 0.0526 & 1 & 0.2584 & 0.0551 & 0.5054 & 0.5595 \\
SUGAR & -0.1105 & -0.3807 & 0.2584 & 1 & -0.1864 & 0.1699 & 0.3253 \\
OIL & 0.5489 & -0.0539 & 0.0551 & -0.1864 & 1 & -0.0768 & 0.1254 \\
KEROS & 0.1953 & 0.3310 & 0.5054 & 0.1699 & -0.0768 & 1 & -0.0487 \\
EGG & 0.4006 & 0.0469 & 0.5595 & 0.3253 & 0.1254 & -0.0487 & 1 \\
\hline Source:
\end{tabular}

Source: Data Proceed, 2020 